\title{
Kaiser effect in historic timber elements
}

\author{
M. Strojecki $\cdot$ C. Colla $\cdot$ M. Lukomski • \\ E. Gabrielli
}

Received: 5 April 2013/Published online: 8 September 2013

(C) The Author(s) 2013. This article is published with open access at Springerlink.com

\begin{abstract}
Timber elements are major structural and architectural components in historic buildings and at the same time belong to the category of materials vulnerable to degradation. The recovery of 150 -year old timber beams from a roof of a historic building made possible the nondestructive investigation of their response to cyclic loading. The experimental study carried out using the acoustic emission technique provided evidence that historic wood shows the load memory known as the Kaiser effect. The effect was observed for different loading and unloading time windows. The observations open up a new perspective for the determination of defects in wooden objects and constructions, important for assessing their possible structural instability.
\end{abstract}

\section{Kaiser-Effekt in historischen Holzbalken}

Zusammenfassung $\mathrm{Holz}$ ist ein wichtiger tragender und architektonischer Baustoff in historischen Gebäuden, aber gehört gleichzeitig zur Kategorie zerstörungsanfälliger Materialien. An 150 Jahre alten Holzbalken aus dem Dach eines historischen Gebäudes konnte deren Verhalten bei zyklischer Belastung zerstörungsfrei untersucht werden. In Laboruntersuchungen konnte mittels Schallemissionsanalyse nachgewiesen werden, dass historisches Holz das als

M. Strojecki · M. Łukomski ( $\square)$

Jerzy Haber Institute of Catalysis and Surface Chemistry, Polish Academy of Sciences, ul. Niezapominajek 8, 30-239 Kraków, Poland

e-mail: nclukoms@cyf-kr.edu.pl

C. Colla $\cdot$ E. Gabrielli

DICAM Department, School of Engineering and Architecture,

Alma Mater Studiorum, Bologna University,

Viale Risorgimento 2, 40136 Bologna, Italy
Kaiser-Effekt bekannte Erinnerungsvermögen an frühere Belastung aufweist. Dieser Effekt wurde bei unterschiedlichen Belastungs- und Entlastungszyklen beobachtet. Diese Ergebnisse eröffnen neue Perspektiven hinsichtlich der Bestimmung von Schäden in Holzbauteilen und -konstruktionen, was für die Beurteilung eventueller baulicher Instabilität wichtig ist.

\section{Introduction}

The Acoustic Emission (AE) method is known to be an excellent monitoring technique for tracing damage development in materials. It is defined as energy released due to micro-displacements in a structure undergoing deformation. The energy passes through the material as ultrasound and sound waves and is typically detected at the surface using piezoelectric transducers which convert the surface vibration into an electrical signal. For more than 50 years, $\mathrm{AE}$ has been successfully applied in civil engineering and material science. A passive mode of collecting signals and high sensitivity make the $\mathrm{AE}$ a powerful tool for monitoring the structural integrity and healthy condition of various objects and structures (Suarez del Rio et al. 2010; Accardo et al. 1983; Jakieła et al. 2007; Carpinteri et al. 2007, Strojecki et al. 2013).

The AE technique is particularly suitable for monitoring structural elements made of metals, due to crystalline structure as well as their isotropy and high homogeneity. In most metals, $\mathrm{AE}$ is not observed during the reloading of a structure until the stress exceeds its previous value. This ability to memorize the highest stress level already experienced was discovered in the early 1950s and was termed the Kaiser effect (Kaiser 1953). Studies by Li and Nordlund (1993); Lavrov (2001) and Ko and Yu (2008) 
demonstrated the occurrence of the Kaiser effect also in mineral construction materials like stones or concrete.

Studying the Kaiser effect in organic materials, such as wood, is hindered by stress relaxation higher than in metals and inorganic construction materials, and high mutability of material stiffness as a function of moisture content. These factors may adversely affect the material ability to store memory of a given load configuration. Therefore, despite the great importance of wood as a modern and historic construction material, there are few studies of this phenomenon in timber structural elements. The most comprehensive tensile and torsion tests were performed by Kánnár (2000) and Chen et al. (2006); both reports concluded that the loading history for most tested specimens was erased after just 2 weeks. Also, significant acoustic emissions were recorded at stress levels below the previous maxima-a phenomenon known as the Felicity effect (Bucur 2006). The Felicity effect is generally associated with structurally significant flaws in the material. In both the studies, only new seasoned wood was examined, therefore, the conclusions cannot be generalized to historic wood which might exhibit different ultra- and microstructure influencing its mechanical properties.

The aim of this work is to get insight into the mechanical behaviour of historic wood by a systematic study of the Kaiser effect using the AE method.

\section{A case study}

The Prosperi-Sacrati palace is one of the buildings located at the famous intersection of the principal streets of the socalled "Herculean Addition" built in Ferrara, Italy, by Ercole I d'Este at the end of the 15th C. (see Fig. 1); the most famous Palazzo dei Diamanti is also located at the same intersection. The Prosperi-Sacrati building was completed in 1513-1514 but its façade was altered in 1857 and the introduction of new roof beams can be traced back to this date. A limited number of these were removed in 2006, due to a significant decay which had occurred at the support ends in contact with the masonry walls. Some of the discharged beams were recovered by the University of Bologna. A dismounted beam, identified as spruce on the basis of visual inspection and existing historic records, with a bevelled-edges rectangular cross-section of about $25 \times 29 \mathrm{~cm}^{2}$ and length of approximately $6 \mathrm{~m}$, has been used in this laboratory experimental work.

The visual inspection of the beam's cross-section revealed also the age of the fallen tree to be more than 90 years and its original arrangement on the roof could be clearly deduced from the degradation state of the surface in contact with the masonry supports. From the central part of the beam, four smaller specimens, about $2.6 \mathrm{~m}$ in length,

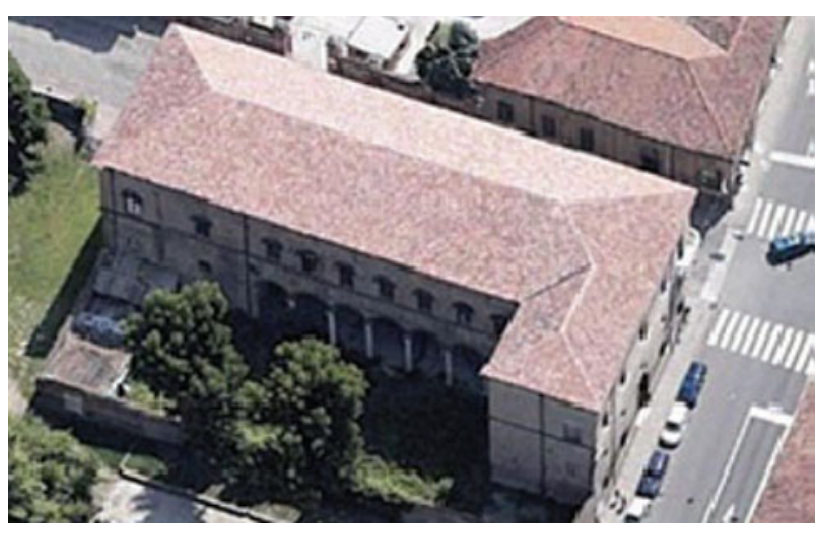

Fig. 1 Aerial view of the Prosperi-Sacrati palace Abb. 1 Luftaufnahme des Prosperi-Sacrati Palasts

were obtained by cutting the original element along the two symmetry axes of the cross-section, see Fig. 2. Bending tests coupled with AE monitoring were performed for three of the four specimens (1, 3 and 4) in 2010 and for two specimens (3 and 4) in 2011.

\section{Experimental programme}

The laboratory study was carried out in Bologna University by monitoring AE during cyclic loading of specimens 1,3 and 4 (Fig. 2) in 4-point bending tests in the elastic range. The testing was done in two separate sessions: February 2010 and March 2011. During the tests, a well-defined and repeatable load pattern in bending mode-the type of deformation commonly present in roof constructions-was selected. The load was applied using a single hydraulic jack, a stiff steel beam and two hinge devices transferring in two points the total force from the actuator. The total length of each beam was $258 \mathrm{~cm}$ but the clear span was only $120 \mathrm{~cm}$ and the distance between the loading points was $40 \mathrm{~cm}$ (see Fig. 3a). The relatively short span facilitated the $\mathrm{AE}$ measurements in which a single analyser collected the AE signal from two sensors located in the middle and at the end of the clear span. A short distance between the sensors allowed the length of cables and therefore possible noise generated in the measuring system to be reduced. The displacement at mid-span was monitored near the lateral faces by two LVDT sensors with $50 \mathrm{~mm}$ range (see Fig. 3b). The test speed in terms of the imposed displacement, monitored in real time, was kept almost constant in all test sessions at values close to $1 \mathrm{~mm} /$ $\min$. The data acquisition was set at 2 data/sec.

The patterns of loading used in years 2010 and 2011 for beams no. 1, 3 and 4 are summarized in Table 1 . The stress acting on the beam mid-span that is subjected to the bending moment is evaluated as flexural stress: 

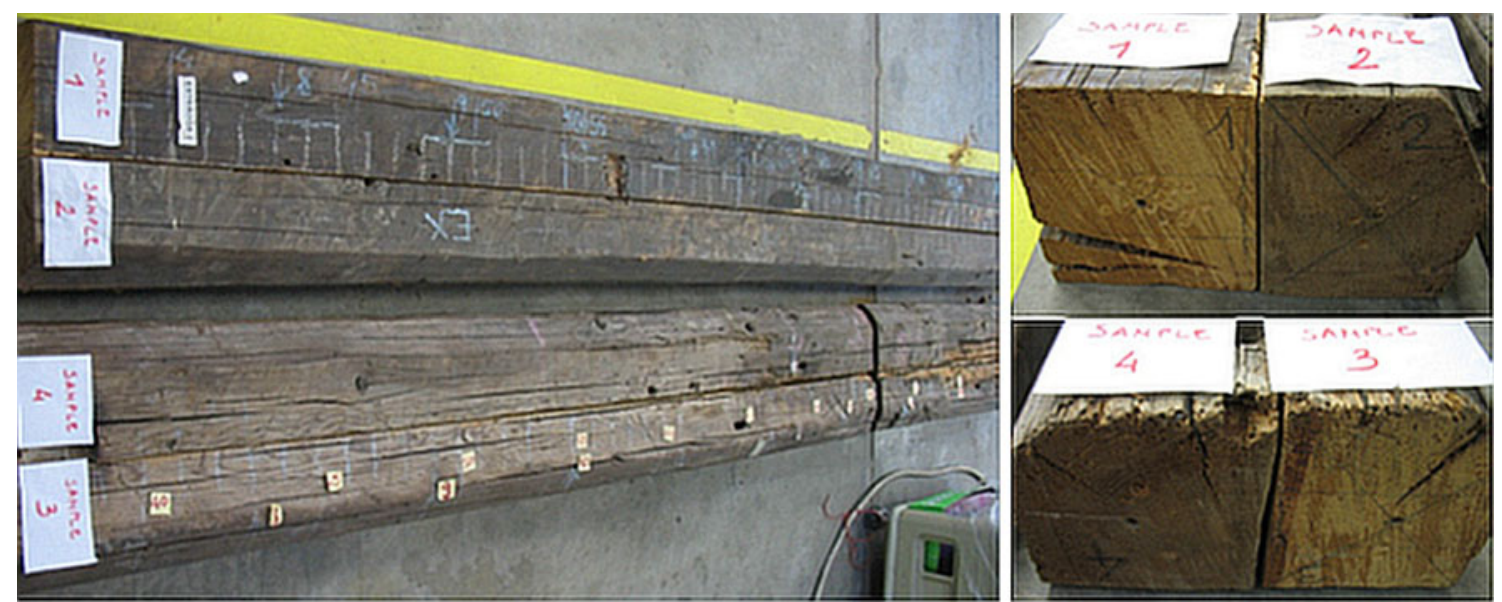

Fig. 2 Specimens cut from the spruce beam recovered from Prosperi-Sacrati palace (left), top and bottom parts of the obtained specimens (right) Abb. 2 Links: Entnahme der Prüfkörper aus den vom Prosperi-Sacrati-Palast stammenden Fichtenbalken, rechts: Prüfkörper aus dem oberen und unteren Bereich der Balken
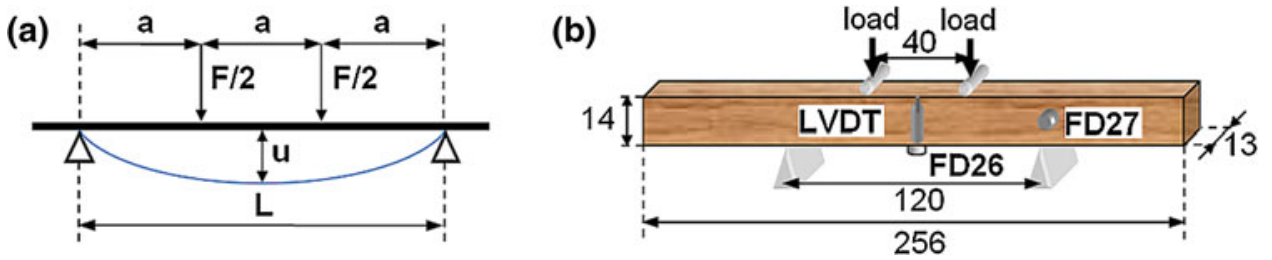

Fig. 3 a Sketch of the load configuration, $\mathbf{b}$ scheme of the 4-point bending test with location of the AE sensors

Abb. 3 Schematische Darstellung des 4-Punkt-Biegeversuchs: a Belastung und b Prüfkörper mit Position der AE-Sensoren

$\sigma=3 F a / b h^{2}$

where $F$ is the total load applied, $a$ is the length of the loading span, $b$ and $h$-width and height of the beam, respectively (Fig. 3). According to European standards strength class system (for example EN 338), the characteristic strength value in bending for high quality structural timber is $40 \mathrm{MPa}$. Values of maximum stresses reached in the applied 4-point bending tests (Table 1) clearly indicate that all loading cycles were performed in the elastic region of wood's deformation.

In the measuring campaigns summarised in Table 1, the effect of a load exceeding the previous level was analysed in two fast loading cycles ( 5 cycles lasted less than $0.5 \mathrm{~h}$ ) applied at a time interval of 1 year (i.e. in February 2010 and March 2011). To make the study consistent and reliable, care was taken to ensure that the experimental procedure during both measurements was exactly the same. It is worth adding that the specimens were kept unloaded between the two measurements in non-air-conditioned laboratory space with temperature and relative humidity varying during the year in the range of $18-30^{\circ} \mathrm{C}$ and $20-60 \%$, respectively.
During all tests (in 2010 and 2011), the settings of the $\mathrm{AE}$ monitoring system, that is gain, frequency filters, sampling rate and threshold level, were the same.

\section{Acoustic emission setup}

AE signals were measured by two (FD26 and FD27) wideband multiresonant piezoelectric sensors (Physical Acoustic Corporation) located, in each experiment, in the middle of the beam and close to the position where load was applied (Fig. 3b). This second sensor was used to double check the operation of the measuring system and to evaluate possible emissions resulting from the pressure of the supporting hinge on the wood during the bending test. The emission from both the sensors was highly correlated proving that noise resulting from processes different than the fracturing of the wood structure did not disturb the measurements. The AE experimental setup consisted further of an acoustic amplifier (EA System) with variable gain and selectable high-pass frequency filters $(5,20$ and $100 \mathrm{kHz}$ ). The AE signals were digitized by a simultaneous-sampling analogue input card PCI-9812 (Adlink 
Table 1 Number of cycles and design load applied at each step for all tests Belastungszyklen und der jeweils aufgebrachten Last bei allen Versuchen
Tab. 1 Anzahl der
${ }^{a}$ Remark: for beam 1, the section height was reduced by $3 \mathrm{~cm}$ in the calculations to take into account a wide and deep fissure in the cross-section present along the entire beam length

\begin{tabular}{|c|c|c|c|c|c|c|c|}
\hline \multirow[b]{2}{*}{ Month } & \multirow[b]{2}{*}{$\begin{array}{l}\text { Cycle } \\
\text { number }\end{array}$} & \multicolumn{2}{|c|}{ Beam 1} & \multicolumn{2}{|c|}{ Beam 3} & \multicolumn{2}{|c|}{ Beam 4} \\
\hline & & $\begin{array}{l}\text { Load } \\
(\mathrm{kN})\end{array}$ & $\begin{array}{l}\sigma^{\max } \\
(\mathrm{MPa})^{\mathrm{a}}\end{array}$ & $\begin{array}{l}\text { Load } \\
(\mathrm{kN})\end{array}$ & $\begin{array}{l}\sigma^{\max } \\
(\mathrm{MPa})\end{array}$ & $\begin{array}{l}\text { Load } \\
(\mathrm{kN})\end{array}$ & $\begin{array}{l}\sigma^{\max } \\
(\mathrm{MPa})\end{array}$ \\
\hline \multirow{5}{*}{$\begin{array}{l}\text { February } \\
2010\end{array}$} & 1 & 5 & 3.8 & 5 & 2.4 & 5 & 2.4 \\
\hline & 2 & 10 & 7.6 & 10 & 4.7 & 10 & 4.7 \\
\hline & 3 & 12 & 9.2 & 12 & 5.7 & 12.5 & 5.9 \\
\hline & 4 & 15 & 11.4 & 15 & 7.1 & 12.5 & 5.9 \\
\hline & 5 & & & 18 & 8.5 & & \\
\hline \multirow{4}{*}{$\begin{array}{l}\text { March } \\
2011\end{array}$} & 1 & & & 10 & 4.7 & 5 & 2.4 \\
\hline & 2 & & & 12 & 5.7 & 10 & 4.7 \\
\hline & 3 & & & 15 & 7.1 & 12.5 & 5.9 \\
\hline & 4 & & & 18 & 8.5 & 15 & 7.1 \\
\hline \multirow{5}{*}{$\begin{array}{l}\text { March } \\
2011 \\
\text { cross } \\
\text { section } \\
\text { rotation } \\
\text { by } 180^{\circ}\end{array}$} & 1 & & & 5 & 2.4 & 5 & 2.4 \\
\hline & 2 & & & 10 & 4.7 & 10 & 4.7 \\
\hline & 3 & & & 12 & 5.7 & 12 & 5.7 \\
\hline & 4 & & & 15 & 7.1 & 15 & 7.1 \\
\hline & 5 & & & 18 & 8.5 & 18 & 8.5 \\
\hline
\end{tabular}

Technology Inc.) and stored in a personal computer used also for post-processing the acquired data. The recorded signals were sampled with the rate of $1 \mathrm{MHz}$. A single data set consisted of 128000 points corresponding to $128 \mathrm{~ms}$ time-windows, while the duration of a typical AE event was of the order of hundreds of $\mu$ s. The dead time between two consecutive data sets was found to be around $100 \mathrm{~ms}$. The storage was triggered when the electrical signal produced by the AE event first crossed the threshold voltage of $0.6 \mathrm{~V}(56 \mathrm{~dB})$ which was twofold that of the continuous background noise $(0.3 \mathrm{~V}$ corresponding to $50 \mathrm{~dB})$. It was also verified in supplementary tests that the testing machine did not generate AE signals when operating without any specimen installed.

The analysing software was designed to search for individual AE events, extract them and calculate the most important AE features, that is, amplitude, energy, duration and frequency distribution.

\section{Results and discussion}

The aim of the study performed in February 2010 was to investigate a short-term Kaiser effect in construction elements made of historic wood by analysing the load curves and the AE data in a 4-point bending experiment with consecutively increased load. The second measuring campaign in March 2011, carried out on the same specimens, sought to establish if historic timber retained memory of the loads imposed during the February 2010 tests, i.e. if a long-term Kaiser effect (the memory of loading exerted 1 year before the tests) was detected. As the stress experienced by the specimen is highest at the mid-span, emissions recorded at this location were taken as the indicator of progressive damage.

\subsection{Year 2010}

The results of bending tests (load and displacement in the middle of the beam) as well as AE signals registered by the sensor located in the middle of beam for specimens 1,3 and 4 are presented in Fig. 4. Much lower AE energy registered for beam three resulted from the application of a particularly severe regime of high-pass frequency filtering $(100 \mathrm{kHz})$ in the detection system. Frequency filtering was applied to increase the signal-to-noise ratio by reducing environmental low-frequency noise. However, various frequency filtering did not overshadow the observed phenomenon in any of the tested beams.

It is clearly visible that AE activity strongly depends on the stress level exerted on the material, that is, increases with increasing load and displacement. In each load cycle, AE activity was observed only above the maximum load that had been exerted on the material in a preceding loading cycle, marked in Fig. 4 with a dashed line. The results presented clearly point to an almost perfect shorttime Kaiser effect that occurs in the tested historic timbers.

\subsection{Year 2011}

The experiments performed in 2010 were repeated after 1 year on specimens 3 and 4 to verify if a long-term Kaiser effect is observed for historic wood. 

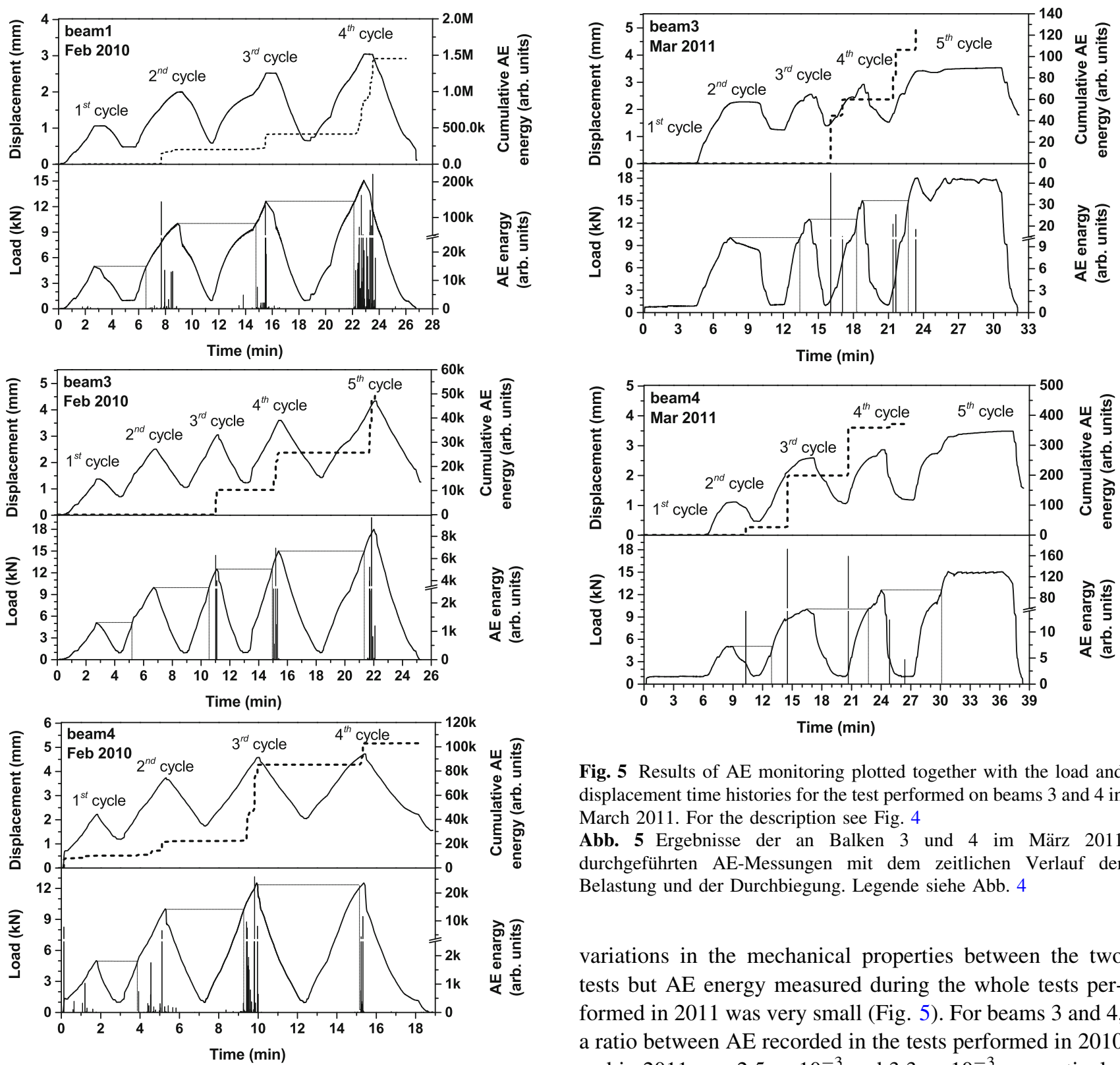

Fig. 5 Results of AE monitoring plotted together with the load and displacement time histories for the test performed on beams 3 and 4 in March 2011. For the description see Fig. 4

Abb. 5 Ergebnisse der an Balken 3 und 4 im März 2011 durchgeführten AE-Messungen mit dem zeitlichen Verlauf der Belastung und der Durchbiegung. Legende siehe Abb. 4

variations in the mechanical properties between the two tests but $\mathrm{AE}$ energy measured during the whole tests performed in 2011 was very small (Fig. 5). For beams 3 and 4, a ratio between $\mathrm{AE}$ recorded in the tests performed in 2010 and in 2011 was $2.5 \times 10^{-3}$ and $3.3 \times 10^{-3}$, respectively. Hence, the AE monitoring confirmed the existence of load memory in historic timber at a 'long timescale', already evident in the results of February 2010 for a 'short timescale'.

To provide further evidence that the analyzed historic wood shows the Kaiser effect, the test was repeated in a different configuration. Beams 3 and 4 were turned around by $180^{\circ}$ in the testing machine and the same mechanical 4-point bending cycles were performed but in the direction opposite to the one loaded before. As the release of acoustic energy occurs at locations where stress concentrations exist due to local structural discontinuities, loading the element in a different direction than previously should lead generally to new local deformation-and related $\mathrm{AE}$ - relieving high local stresses. The results presented in 

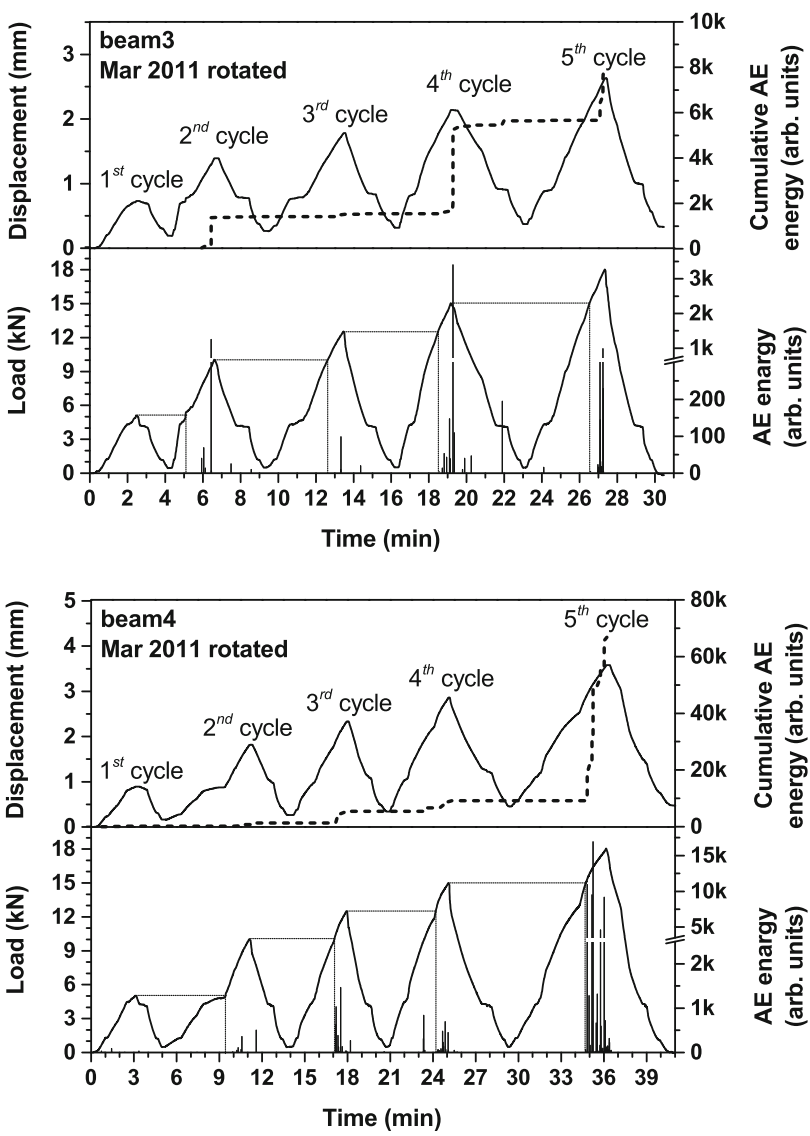

Fig. 6 Results of AE monitoring plotted together with the load and displacement time histories for the test performed on beams 3 and 4 (cross section rotation by $180^{\circ}$ ) in March 2011. For the description see Fig. 4

Abb. 6 Ergebnisse der an Balken 3 und 4 (Prüfkörper um 180 gedreht) im März 2011 durchgeführten AE-Messungen mit dem zeitlichen Verlauf der Belastung und der Durchbiegung. Legende siehe Abb. 4
Fig. 6 indeed confirm this expectation. Energy was emitted in each loading cycle. When the structure was unloaded and then re-loaded, little AE was observed unless the load exceeded the previous maximum. Hence, the short-term Kaiser effect was observed (as in the measurements in 2010 presented in Fig. 4) and a relatively high value of AE energy was recorded.

Results of all tests revealing the stress memory in the analysed historic wood specimens are summarised in Table 2. For each loading cycle, the ratio between AE energy registered for loads lower and higher than the maximum load reached in the previous cycle is provided. A ratio of zero corresponds to the perfect Kaiser effect whereas a high value of this parameter corresponds to a big Felicity effect meaning that AE signals are detected before the maximum value of the load from the previous cycle is exceeded. In the presented tests, the ratio exceeded 0.1 only in 3 of 18 loading cycles measured, which shows that the observed short-term Kaiser effect is distinct for the tested specimens.

\section{Conclusion}

Bending tests conducted on specimens obtained from a 150-year old spruce timber beam recovered from the roof structure of a historic building in Ferrara, Italy, combined with $\mathrm{AE}$ monitoring revealed stress memory in naturally aged wood. The experiments consisting of subjecting the specimens to the same loading pattern first in 2010 and then a year later clearly showed that AE signals appeared only when the previously exerted load was exceeded, even if the previous load had been exerted 1 year before. Hence,
Table 2 Results showing the Kaiser effect in the analysed specimens

Tab. 2 Ergebnisse, die den Kaiser-Effekt in den untersuchten Prüfkörpern zeigen

The following high-pass filters were applied in the $\mathrm{AE}$ measurements: $5 \mathrm{kHz}$ (beam 1), $100 \mathrm{kHz}$ (beam 3) and $20 \mathrm{kHz}$ (beam 4)

Folgende Hochpassfilter wurden bei den AE-Messungen verwendet: $5 \mathrm{kHz}$ (Balken 1), $100 \mathrm{kHz}$ (Balken 3) und $20 \mathrm{kHz}$ (Balken 4)

${ }^{a}$ defined as ratio of $\mathrm{AE}$ energies registered below and above load exerted in the preceding cycle

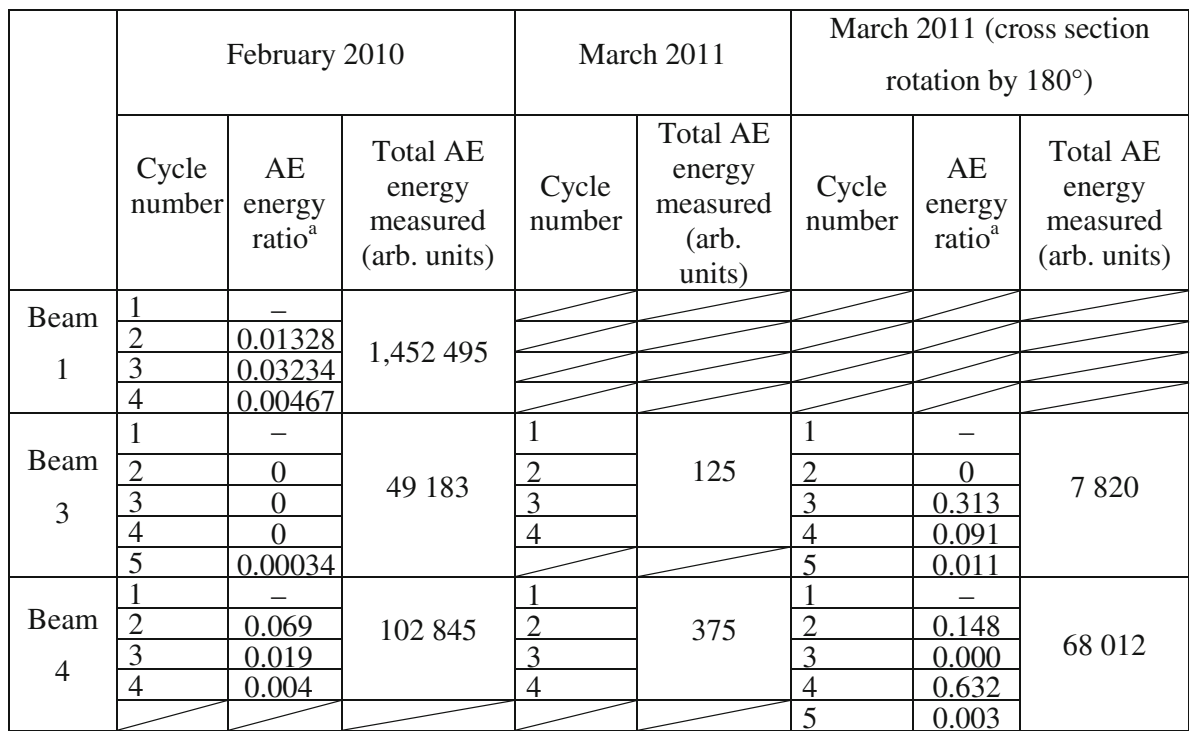


both short- and long-term Kaiser effect was revealed. The Felicity effect was minimal.

In the analysed load range, the observed long-term Kaiser effect was almost perfect. Even variations in temperature and relative humidity typical of uncontrolled indoor climate in the laboratory building in which the beams were stored between consecutive measuring campaigns, did not disturb a clear manifestation of the effect.

This observation opens up a new perspective for using AE monitoring for the determination of structurally significant defects in wooden works of art and constructions. No emission if past maximum load is not exceeded would point to insignificant flaws (discontinuities) in the material. In turn, emission at a load below the past maximum or emission that continues at constant loads, are likely to indicate significant defects in the material and structural instability which should be verified by further investigations.

Acknowledgments This research was carried out within the Smart Monitoring of Historic Structures (SMooHS) project, financially supported by the European Commission 7th Framework Programme, Theme 6: Environment. Grant agreement no 212939 (www.smoohs. eu). The testing facilities of the LISG laboratory of University of Bologna are gratefully acknowledged as well as the kind availability of Prof. A. Benedetti, lab coordinator, for use of the tested timber specimens.

Open Access This article is distributed under the terms of the Creative Commons Attribution License which permits any use, distribution, and reproduction in any medium, provided the original author(s) and the source are credited.

\section{References}

Accardo G, Caneva C, Massa S (1983) Stress monitoring by temperature mapping and acoustic emission analysis: a case study of Marcus Aurelius. Stud Conserv 28(2):67-74
Bucur V (2006) Acoustic of wood. Springer-Verlag, Berlin

Carpinteri A, Lacidogna G, Niccolini G (2007) Acoustic emission monitoring of medieval towers considered as sensitive earthquake receptors. Nat Hazards Earth System Sci 7:1-11

Chen Z, Gabbitas B, Hunt D (2006) Monitoring the fracture of wood in torsion using acoustic emission. J Mater Sci 41(12):36453655

Jakieła S, Bratasz Ł, Kozłowski R (2007) Acoustic emission for tracing the evolution of damage in wooden objects. Stud Conserv 52(2):101-109

Kaiser J (1953) Erkenntnisse und Folgerungen aus der Messung von Geräuschen bei Zugbeanspruchung von metallischen Werkstoffen. In: Archiv für das Eisenhüttenwesen, 24, Nr. 1-2

Kánnár A (2000) Kaiser effect experiments in wood by acoustic emission testing. In: Proceedings of the 12th International Symposium on Nondestructive Testing of Wood, University of Western Hungary, Sopron, pp 393-401

Ko WC, Yu CW (2008) Study of Kaiser effect in concrete material under cyclic loading. In: Proceedings of IAES-19:295-302

Lavrov A (2001) Kaiser effect observations in brittle rock cyclically loaded with different loading rates. Mech Mate 33:669-677

Li C, Nordlund E (1993) Experimental verification of the Kaiser effect in rocks. Rock Mech Rock Eng 26(4):333-335

Strojecki M, Łukomski M, Colla C, Gabrielli E (2013) Acoustic emission as a non-destructive method for tracing damage: from laboratory testing to monitoring historic structures. In: Nondestructive testing of materials and structures, RILEM Bookseries vol. 6, pp 1131-1136

Suarez del Rio LM, Ruiz de Argandoña VG, Calleja L, RodriguezRey A, Grossi-Sampedro CM, Montoto M (2010) Acoustic Emission monitoring of the Cathedral of Palma de Mallorca (Spain), In: M. Bostenaru Dan, R. Přikryl, Á. Török (eds.) Materials, technologies and practice in historic heritage structures, part IV, Springer pp 351-365 